\title{
Yield and Water Use Efficiency of Potato under Alternate Furrows and Deficit Irrigation
}

\author{
Kassu Tadesse Kassaye $(\mathbb{D}$, Wubengeda Admasu Yilma, Mehiret Hone Fisha, \\ and Dawit Habte Haile
}

Kulumsa Agricultural Research Center, P.O. Box 489, Kulumsa, Ethiopia

Correspondence should be addressed to Kassu Tadesse Kassaye; kasstad96@yahoo.com

Received 26 July 2020; Revised 22 October 2020; Accepted 28 October 2020; Published 24 November 2020

Academic Editor: Wei Wu

Copyright (c) 2020 Kassu Tadesse Kassaye et al. This is an open access article distributed under the Creative Commons Attribution License, which permits unrestricted use, distribution, and reproduction in any medium, provided the original work is properly cited.

\begin{abstract}
The benefits of water-saving techniques such as alternate furrow and deficit irrigations need to be explored to ensure food security for the ever-increasing population within the context of declining availability of irrigation water. In this regard, field experiments were conducted for 2 consecutive dry seasons in the semiarid region of southwestern Ethiopia and investigated the influence of alternate furrow irrigation method with different irrigation levels on the yield, yield components, water use efficiency, and profitability of potato production. The experiment comprised of 3 irrigation methods: (i) conventional furrow irrigation (CFI), (ii) alternate furrow irrigation (AFI), and (iii) fixed furrow irrigation (FFI) combined factorially with 3 irrigation regimes: (i) 100\%, (ii) $75 \%$, and (iii) $50 \%$ of the potato water requirement $\left(\mathrm{ET}_{\mathrm{C}}\right)$. The experiment was laid out in randomized complete block design replicated thrice. Results revealed that seasonal irrigation water applied in alternate furrows was nearly half $(170 \mathrm{~mm})$ of the amount supplied in every furrow $(331 \mathrm{~mm})$. Despite the half reduction in the total amount of water, tuber $\left(35.68 \mathrm{tha}^{-1}\right)$ and total biomass (44.37 tha $\mathrm{th}^{-1}$ ) yields of potato in AFI did not significantly differ from CFI ( 34.84 and $45.35 \mathrm{tha}^{-1}$, respectively). Thus, AFI improved WUE by $49 \%$ compared to CFI. Irrigating potato using $75 \%$ of $\mathrm{ET}_{\mathrm{C}}$ produced tuber yield of $35.01 \mathrm{tha}^{-1}$, which was equivalent with $100 \%$ of $\operatorname{ET}_{\mathrm{C}}\left(35.18 \mathrm{tha}^{-1}\right)$. Irrigating alternate furrows using $25 \%$ less $\mathrm{ET}_{\mathrm{C}}$ provided the highest net return of US $\$ 74.72$ for every unit investment on labor for irrigating potato. In conclusion, irrigating alternate furrows using up to $25 \%$ less $\mathrm{ET}_{\mathrm{C}}$ saved water, provided comparable yield, and enhanced WUE and economic benefit. Therefore, farmers and experts are recommended to make change to AFI with $25 \%$ deficit irrigation in the study area and other regions with limited water for potato production to improve economic, environmental, and social performance of their irrigated systems.
\end{abstract}

\section{Introduction}

Ethiopian farming is mainly dependent on rain-fed smallholder agricultural system. In the absence of sufficient rainfall, there is always low agricultural production, thereby creating food shortage and food insecurity [1]. In this regard, the contribution of irrigated agriculture is substantial. The traditional and small-scale irrigations cover the lions share in the Ethiopian irrigated agriculture [2]. The main sources of water for irrigation in Ethiopia are diversion from rivers, spring development, and surface reservoirs, whereas the common method of water application is furrow irrigation [3]. The irrigated agriculture is plagued by inappropriate on- farm water management, which resulted in adverse effects such as nonuniform water distribution, unbalanced crop growth, water logging, salinity, and erosion, thereby led to low production and productivity. Consequently, most of the developed irrigation schemes are benefiting under their designed potential area and period [2,4].

Despite the alarmingly increasing population and the great desire to boost production, scarcity of irrigation water has now become the main constraint for crop production particularly in arid and semiarid areas, where evapotranspiration is very high, but the seasonal rainfall is low, erratic, and unreliable for crop production $[5,6]$. Consequently, repeated crop failure has been a common experience in the 
country $[1,5]$ in general and in study area in particular. The growing demand for more food and fiber is met through increasing irrigated agriculture. This translates into a significantly increasing pressure on the country's available water resources in the coming years. It is therefore critical to improve water management and utilization at the field scale through adoption of more efficient and effective irrigation methods $[1,4,5,7]$.

Nearly $90 \%$ of the irrigated land of the world is watered using the least efficient traditional methods of irrigation [8]. Among such traditional methods is conventional furrow irrigation (CFI) method, which is widely practiced across Ethiopia for watering row crops $[1,4]$. The CFI schemes consume huge amount of water $[7,9]$, but their field application efficiency are still very low, usually less than $50 \%$ [10]. In response to the wastage of the limited water resources, adoption of the most efficient methods such as drip and sprinkler irrigation systems is increasingly advocated for increasing yield and water use efficiency of different crops [11-13]. However, these methods have not yet been widely adopted among farmers due to their high cost of initial investments, installation, operation, maintenance, and demand for technical knowledge [14]. Such farmers, therefore, need low-cost, simple, easy to install and operate but more efficient and water-saving techniques such as alternate furrow irrigation (AFI) and deficit irrigation (DI).

The water use efficiency (WUE) of CFI could significantly be improved and substantial amount of water saved without significant yield reduction by renovating to alternate furrow irrigation (AFI) technique [15-17]. AFI method or alternate wetting and drying of the root zone has been introduced from the partial root zone drying technique. It is an alternate irrigation of one furrow while keeping the adjacent furrow dry until the next irrigation event [9, 18-20]. Irrigating only one side of furrows implies a substantial potential for reducing water use with minute influence on photosynthetic rate compared to CFI $[7,14]$. Studies presented $28-50 \%$ irrigation water savings in AFI for various crops, e.g., potato, tomato, okra, and maize, with insignificant reduction in yield $[7,14,21,22]$.

Deficit irrigation (DI) is a practice of water supply by reducing the amount below the optimal level of crop evapotranspiration $[18,19,23]$. The controlled DI induces some level of stress to the crops reducing water use while minimizing adverse impacts on the yield [14, 21, 24]. The adoption of DI can enhance agricultural production per unit volume of water by increasing cultivable frequency or intensifying irrigable land using the existing water resources [21, 24-26]. Regulated DI induced $20-72 \%$ increase in WUE on various crops such as potato, maize, tomato, and grape with minimal effect on yield reduction $[9,21,24,27]$. Studies further indicated that watersaving practices such as application of compost and mulching and fertilizer management could offset the negative effects of deficit irrigation on crops' performances.

Potato (Solanum tuberosum L.) is one of the most important tuber crops in the world in general and Ethiopia in particular and grown by 1.13 million smallholder farmer [28] in dry season (October-May) using traditional furrow irrigation method. It is a staple food and cash crop among the wider community and plays vital role in the food security [29]. The area under potato cultivation and its total production expanded from 50,488 to 69,610 ha and from 402,508 to 968,970 tons between 2008 [30] to 2018 [28]. Despite the intensification both in area and total production by 38 and $141 \%$, respectively, during the last 10 years, the quality and national average is still very low $\left(14 \mathrm{tha}^{-1} ;[28]\right)$ compared to the world average $\left(21 \mathrm{tha}^{-1}\right)$ and top producing countries (e.g., Australia, Canada, and Egypt; 43, 40, and $30 \mathrm{tha}^{-1}$, respectively) [31]. Among the yield constraining factors, limited available irrigation water and its improper management take the lead share.

In this regard, we hypothesized that the adoption of AFI along with regulated DI techniques would maintain tuber yield, reduce water use, and enhance the WUE of potato production in semiarid areas of Ethiopia, where water resources are scarce. However, the feasibility of both AFI and DI techniques has not yet been well investigated for potato production in the southwestern part of Ethiopia, and the available reports are still limited. In response to this research gap, we conducted field experiments and compared potato grown in AFI with conventional (CFI) and fixed furrow irrigation (FFI) each with 3 levels of irrigation. Thus, the objective of this study was to evaluate the influence of AFI with different irrigation levels on the growth, yield, yield components, water use efficiency, and profitability of potato production in contrast to the conventional (CFI) and fixed furrow irrigation (CFI) methods under the semiarid areas of southwest Ethiopia with limited water resources.

\section{Materials and Methods}

2.1. Descriptions of the Study Area. This study was conducted at the farmer's field in the district of Ziway Dugeda, Arsi Zone $\left(08^{\circ} 00^{\prime} 13.6^{\prime \prime} \mathrm{N}\right.$ and $\left.39^{\circ} 01^{\prime} 7.3^{\prime \prime} \mathrm{E}\right)$, which is located in the semiarid climatic region of southwest Ethiopia. The experiment was undertaken during the dry season (December-April) in 2013 and 2014. The elevation at the site was $1689 \mathrm{~m}$ above sea level. The major soil type of the study area was classified as Andosol [32]. The soil texture was clay loam. The measured mean bulk density and saturated hydraulic conductivity of the studied soil were $1.15 \mathrm{~g} \mathrm{~cm}^{-3}$ and $19.2 \mathrm{~cm} \mathrm{day}^{-1}$, respectively. The chemical analysis conducted for the surface soil samples $(0-20 \mathrm{~cm})$ of the study area were $\mathrm{pH}$, total nitrogen (TN), available phosphorous (avail $\mathrm{P}$ ), and organic matter content (OM). Accordingly, the $\mathrm{pH}, \mathrm{TN}$, avail $\mathrm{P}$, and $\mathrm{OM}$ contents of the soil were $6.3,0.08 \%$, $12.94 \mathrm{mg} \mathrm{kg}^{-1}$ soil, and $2.59 \%$, respectively. Thus, the site was characterized as slightly acidic [33] and low in statuses of $\mathrm{TN}$, avail $\mathrm{P}$, and $\mathrm{OM}$ contents $[33,34]$.

There were no weather stations at the study sites. Thus, the New_Loclim: Local Climate Estimator, a public domain software program and database, developed by FAO [35] was used to estimate the average weather variables for the study sites. The programme can extract and display weather data from the FAOCLIM [36] database of many stations utilizing geographic coordinate and elevation as the input. For areas with no weather station, the programme generates data by 
TABLe 1: Treatments setting for the field experiment.

\begin{tabular}{lc}
\hline Irrigation system & Amount of irrigation water (\% ETc) \\
\hline Alternate furrow irrigation (AFI) & 50 \\
Alternate furrow irrigation (AFI) & 75 \\
Alternate furrow irrigation (AFI) & 100 \\
Fixed furrow irrigation (FFI) & 50 \\
Fixed furrow irrigation (FFI) & 75 \\
Fixed furrow irrigation (FFI) & 100 \\
Conventional furrow irrigation (CFI) & 50 \\
Conventional furrow irrigation (CFI) & 75 \\
Conventional furrow irrigation (CFI) & 100 \\
\hline
\end{tabular}

Note: ETc is the potato seasonal water requirement.

interpolating from the nearby weather stations. Employing the program, 8 weather variables including monthly means of minimum, maximum and average daily temperature, precipitation, and evapotranspiration were obtained. Accordingly, the mean annual precipitation of the study site was $689 \mathrm{~mm}$. The average monthly maximum and minimum air temperatures were 26.3 and $12.3^{\circ} \mathrm{C}$, respectively. The average value of the reference evapotranspiration $\left(\mathrm{ET}_{\mathrm{O}}\right)$ of the study area during the growing period was $3.82 \mathrm{~mm} \mathrm{day}^{-1}$, which varied from $4.28 \mathrm{~mm} \mathrm{day}^{-1}$ in March to $3.21 \mathrm{~mm} \mathrm{day}^{-1}$ in September.

2.2. Experimental Setup and Procedure. The treatments comprised of 9 combinations of 3 furrow irrigation methods and 3 irrigation levels. The 3 irrigation methods were (i) conventional furrow irrigation, (ii) alternate furrow irrigation, and (iii) fixed furrow irrigation. In CFI, water was supplied to every furrow in every irrigation events. In AFI, water was applied to alternate furrows. However, during the subsequent event, irrigation water was applied to the alternate furrows that had been kept dry during the previous time while leaving previously wet furrows not irrigated. In FFI, irrigation water was supplied to the fixed furrows while the adjacent furrows kept dry from first to last irrigation events. The 3 irrigation levels were (i) $100 \%$, (ii) $75 \%$, and (iii) $50 \%$ of the potato water demand. The 3 irrigation methods were combined with the other 3 irrigation levels factorially comprising of a total of 9 treatments as shown in Table 1 . The experiment was laid out in randomized complete block design with 3 replications.

\subsection{Determination of Crop Water and Irrigation} Requirements. The reference evapotranspiration $\left(\mathrm{ET}_{\mathrm{O}}\right)$ from the potato field was computed employing FAO Penman-Monteith equation [37] implemented in the CROPWAT 8.0 model [38]. The $\mathrm{ET}_{\mathrm{o}}$ of the experimental site was computed from minimum and maximum air temperatures, wind speed, relative humidity, sunshine hours, and solar radiation using the FAO CROPWAT 8.0 model. The crop evapotranspiration $\left(\mathrm{ET}_{\mathrm{C}}\right)$ was calculated by multiplying the $\mathrm{ET}_{\mathrm{O}}$ with crop coefficient $\left(K_{\mathrm{C}}\right)$ at each crop growth stage using CROPWAT 8.0 model and Microsoft Excel 2010 spreadsheet (Microsoft ${ }^{\circledR}$ Corp., Redmond, Washington, USA) over the growing season
(Equation 1). Since there were no site specific $K_{\mathrm{C}}$ for potato in the study area, the values set by FAO [37] for the 4 crop development stages were adopted for this study:

$$
\mathrm{ET}_{\mathrm{C}}=\mathrm{ET}_{\mathrm{O}} * K_{\mathrm{C}} \text {, }
$$

where $\mathrm{ET}_{\mathrm{C}}, \mathrm{ET}_{\mathrm{O}}$, and $K_{\mathrm{C}}$ are crop evapotranspiration $\left(\mathrm{mm}\right.$ day $\left.^{-1}\right)$, reference crop evapotranspiration $\left(\mathrm{mm} \mathrm{day}^{-1}\right)$, and crop coefficient (dimensionless), respectively.

The total length of the test crop's growing period in the study area ranged from 120-130 days. The growing period of potato was divided into initial, development, middle, and late stages [39]. The initial, development, middle, and late stages run from the sowing date to approximately $10 \%$ ground cover, $10 \%$ ground cover to effective full cover, effective full cover to the start of maturity, and start of maturity to harvest (full senescence), respectively [39]. The dates of potato growth stages were determined from the phenology of the crop and its percentage of ground cover.

The optimal or "no stress" or $100 \% \mathrm{ET}_{\mathrm{C}}$ treatment was computed using Equation 1 as the amount of irrigation water needed to refill the root zone of the soil back to field capacity. The computed total seasonal crop water requirement during the experimental period was $331.73 \mathrm{~mm}$. During the same period, however, $132.93 \mathrm{~mm}$ of the crop's demand was fulfilled by the effective rainfall, which was calculated from the seasonal rainfall. Thus, the net irrigation requirement was $198.8 \mathrm{~mm}$. The field application efficiency considered for the method of irrigation used in this study was $60 \%$ [39]. The calculated gross irrigation requirement, which was measured as $100 \%$ ETC, during the experimental period was $331.3 \mathrm{~mm}$. Therefore, the water depths for the treatments with 100,75 and $50 \% \mathrm{ET}_{\mathrm{C}}$ were calculated as $331.3,248.5$, and $165.7 \mathrm{~mm}$, respectively. Irrigation scheduling was also computed employing CROPWAT 8.0 model by considering the crop, climatic, and soil properties of the study area over the growing period.

2.4. Soil and Crop Management. The experimental sites were properly ploughed, and the clods were pulverized with oxdriven local plough called "maresha". The entire experimental site was levelled and demarcated into plots, and each was laid out in $5.1 \mathrm{~m}$ by $3 \mathrm{~m}\left(15.3 \mathrm{~m}^{2}\right)$ area. The furrows and ridges were manually constructed using hand hoes and spades. The ridge top center-to-ridge top center 
(row-to-row) distances were kept $0.75 \mathrm{~m}$. All experimental plots were sown with germinated potato tuber seeds $(c v$ Kulumsa) manually by hand on one side of raised beds on 22 December in 2013 and 02 December in 2014 maintaining a $0.30 \mathrm{~m}$ plant-to-plant distance along the row (ridge). Thus, there were a total of 4 rows (rides) with in each plot and 17 plants within a row comprising of 68 plants per plot. For preventing the lateral movement of water during irrigation from plot to plot, each block and treatment plot was kept 1.5 and $0.5 \mathrm{~m}$, respectively, apart.

The recommended rates of $\mathrm{N}\left(110 \mathrm{~kg} \mathrm{Nha}^{-1}\right)$ and $\mathrm{P}$ $\left(40 \mathrm{~kg} \mathrm{Pha}^{-1}\right)$ for potato in the study area were uniformly applied to all plots from Urea and DAP fertilizers, respectively. All $\mathrm{P}$ and half dose of $\mathrm{N}$ fertilizers were applied at sowing as basal placement while the remaining half of $\mathrm{N}$ was side dressed 1 month later during hilling (earthing up) operation. The experimental plots were always kept free from weeds by manual clearing and hoeing. The Ridomil gold $^{\circledR}$ fungicide was applied against late blight disease of potato. All other agronomic practices were carried out as per the recommendation for potato crop. The potato was manually harvested after physiological maturity on 24 April in 2013 and 12 April in 2014. Thus, the total length of growing period in 2013 and 2014 were 123 and 131 days, respectively, indicating that the later year was a bit longer compared to the former one.

2.5. Irrigation Water Management. The plots were irrigated through a field canal that conveyed water from the nearby Ketar River through the main canal. The amount of irrigation water supplied to the plots was measured using a 2inch partial flume. The parshal flume was installed at a levelled surface few meters before the experimental site. The fixed partial flume was aligned straight with the field canal and levelled laterally and longitudinally to allow free flow of water. The water supply to each furrow within each plot was switched off when the time allotted to each furrow ended indicating the delivery of the calculated amount irrigation water to each plot.

The same amount of irrigation water was uniformly supplied to every furrow of each plot regardless of treatment setup few days prior to sowing to establish a favorable seedbed for sowing potato seeds and their germination. Irrigation water was supplied just after sowing to all plots. Another round of irrigation water was also applied 5 days after sowing to make sure that all potato tuber seeds germinated. Thereafter, the irrigation water was applied according to the treatment setup.

Based on the treatments setup, predetermined amounts of irrigation water were usually discharged to each furrow per each crop development stage and irrigation event for predefined periods of time measured through the parshal flume. The flow rate of the parshal flume, which was usually controlled at the outlet of the field canal, was known. Thus, for the CFI, a furrow was irrigated with known volume of water for the duration of predefined period. When the predefined period ended, the inlet of a furrow was closed and irrigation continued until all furrows within the plot were irrigated for the same duration with similar volume of water. However, for the same level of irrigation treatment (e.g., $100 \%$ ETC), only half of the available furrows within the plot in FFI and AFI methods were irrigated with half volume of water relative to CFI per irrigation event.

2.6. Data Collection. The data collected (computed) during the experimental period were number of tuber per plant, weight of tuber per plant, plant height, total biomass yield, marketable tuber yield, and water use efficiency. The plant height was measured from 10 plant samples from the soil surface to the plant apex at the end of the growing season. Potato tubers were dug out from 5 plant samples, counted, and recorded from each of the sampled potato plants for number and weight of tubers per plant. Just after full physiological maturity and five days prior to harvesting, the haulm of potato was cut and recorded for aboveground biomass yield determination. The marketable potato tubers from the central 2 rows of each plot $\left(7.5 \mathrm{~m}^{2} ; 1.5 \mathrm{~m}\right.$ by $\left.5.1 \mathrm{~m}\right)$ were harvested manually, the fresh weight was measured for tuber yield determination and the values were converted to $\mathrm{tha}^{-1}$ for statistical analysis. The field water use efficiency was calculated by dividing the marketable (economic) potato tuber yield with the total amount of irrigation water applied per treatment and per period as shown in the following equation [40]:

$$
\mathrm{WUE}=\frac{Y}{\mathrm{ETc}}
$$

where WUE is the water use efficiency $\left(\mathrm{kg} \mathrm{m}^{-3}\right), Y$ is the potato tuber yield $\left(\mathrm{kg} \mathrm{ha}^{-1}\right)$, and ETc is the total irrigation water supplied during the experimental period $\left(\mathrm{m}^{3} \mathrm{ha}^{-1}\right)$. The total water included only the supplied irrigation water.

The irrigation water saved with AFI or FFI relative to CFI was calculated using the following equation [41]:

$$
\text { water saving }(\%)=\frac{\theta_{\mathrm{CFI}}-\theta_{\mathrm{AFI}} \text { or } \theta_{\mathrm{FFI}}}{\theta_{\mathrm{CFI}}} * 100 \text {, }
$$

where $\theta_{\mathrm{CFI}}, \theta_{\mathrm{AFI}}$, and $\theta_{\mathrm{FFI}}$ are the total amount of irrigation water $(\mathrm{mm})$ used with the CFI, AFI, and FFI methods, respectively.

2.7. Economic Analysis. In order to evaluate the comparative advantages of the alternate furrow irrigation method and irrigation levels for potato production, economic analysis was conducted following the procedure of partial budget analysis set by CIMMYT [42]. The sole variable cost (VC) during the period of this study was the expense incurred for labor to irrigate the experimental plots. The gross field benefit (GFB) was calculated by multiplying the selling price with the total marketable yield of potato. The VC and GFB were estimated based on the average values over seasons. The net benefit (NB) was calculated by subtracting the VC from GFB. The marginal rate of return (MRR) was calculated as the ratio of marginal $\mathrm{NB}$ and marginal $\mathrm{VC}$ of potato production. The marginal rate of return refers to the amount of additional revenue that farmers can expect to earn per each 
TABLE 2: Combined analysis of variance of potato tuber yield, yield components and water use efficiency for tuber yield as affected by year, irrigation methods (IMs), and irrigation levels (IAs).

\begin{tabular}{|c|c|c|c|c|c|c|}
\hline Source of variation & $\begin{array}{c}\text { No. of tubers } \\
\text { plant }^{-1}\end{array}$ & $\begin{array}{c}\text { Weight of tubers } \\
\text { plant }^{-1}(\mathrm{~g})\end{array}$ & $\begin{array}{l}\text { Plant height } \\
(\mathrm{cm})\end{array}$ & $\begin{array}{c}\text { Total biomass yield (t } \\
\left.\mathrm{ha}^{-1}\right)\end{array}$ & $\begin{array}{c}\text { Tuber yield }(\mathrm{t} \\
\left.\mathrm{ha}^{-1}\right)\end{array}$ & $\begin{array}{c}\text { WUE } \\
\left(\mathrm{kg} \mathrm{m}^{-3}\right) \\
\end{array}$ \\
\hline Replication & 0.0437 & 0.705 & 0.3183 & 0.6244 & 0.5327 & 0.3355 \\
\hline Irrigationmethod (IM) & 0.0075 & 0.0175 & 0.3363 & 0.0114 & 0.0392 & $<0.0001$ \\
\hline Irrigation level (IA) & 0.187 & 0.0251 & 0.4826 & 0.058 & 0.059 & $<0.0001$ \\
\hline $\mathrm{IM}^{*} \mathrm{IA}$ & 0.7638 & $<0.0001$ & 0.0347 & 0.9545 & 0.8735 & 0.2976 \\
\hline Year*IM*IA & 0.1572 & $<0.0001$ & 0.0155 & 0.1337 & 0.3262 & 0.1257 \\
\hline $\mathrm{CV}$ & 20.57 & 22.85 & 5.29 & 21.56 & 26.48 & 25.49 \\
\hline Mean & 9.81 & 1000.61 & 59.19 & 42.08 & 33.02 & 173.39 \\
\hline LSD & 1.3679 & 155.18 & 2.1207 & 6.1449 & 5.9228 & 24.447 \\
\hline
\end{tabular}

Note: WUE is water use efficiency.

TABle 3: Means for the main effects of methods and amount of irrigation water on the yield, yield attributes, and water use efficiency of potato.

\begin{tabular}{|c|c|c|c|c|}
\hline Treatments & No. of tubers plant ${ }^{-1}$ & Total biomass yield $\left(\mathrm{t} \mathrm{ha}^{-1}\right)$ & Tuber yield $\left(\mathrm{t} \mathrm{ha}^{-1}\right)$ & WUE $\left(\mathrm{kg} \mathrm{m}^{-3}\right)$ \\
\hline \multicolumn{5}{|l|}{ Year } \\
\hline 2013 & $7.4^{\mathrm{b}}$ & $31.85^{\mathrm{b}}$ & $27.84^{\mathrm{b}}$ & $141^{\mathrm{b}}$ \\
\hline 2014 & $12.3^{\mathrm{a}}$ & $52.30^{\mathrm{a}}$ & $38.20^{\mathrm{a}}$ & $206^{\mathrm{a}}$ \\
\hline Significance & $<0.0001$ & $<0.0001$ & $<0.0001$ & $<0.0001$ \\
\hline \multicolumn{5}{|c|}{ Irrigation methods } \\
\hline AFI & $9.6^{\mathrm{b}}$ & $44.37^{\mathrm{a}}$ & $35.68^{\mathrm{a}}$ & $224^{\mathrm{a}}$ \\
\hline FFI & $8.8^{\mathrm{b}}$ & $36.52^{\mathrm{b}}$ & $28.55^{\mathrm{b}}$ & $186^{\mathrm{b}}$ \\
\hline CFI & $11.1^{\mathrm{a}}$ & $45.34^{\mathrm{a}}$ & $34.84^{\mathrm{a}}$ & $110^{\mathrm{c}}$ \\
\hline Significance & 0.0075 & 0.0114 & 0.0392 & $<0.0001$ \\
\hline \multicolumn{5}{|l|}{ Irrigation levels } \\
\hline $50 \%$ & 9.1 & $37.64^{\mathrm{b}}$ & $28.85^{\mathrm{b}}$ & $218^{\mathrm{a}}$ \\
\hline $75 \%$ & 10.3 & $43.67^{\mathrm{ab}}$ & $35.03^{\mathrm{a}}$ & $173^{\mathrm{b}}$ \\
\hline $100 \%$ & 10 & $44.93^{\mathrm{a}}$ & $35.18^{\mathrm{a}}$ & $130^{\mathrm{c}}$ \\
\hline Significance & 0.187 & 0.058 & 0.059 & $<0.0001$ \\
\hline
\end{tabular}

Note: AFI, FFI, CFI, and WUE are alternate furrow irrigation, fixed furrow irrigation, conventional furrow irrigation, and water use efficiency, respectively.

one-unit increase in the use of a variable cost (in this case wage) while other production costs are constant. The acceptable MRR considered to declare profitability in this study was greater than or equal to $100 \%$. The marketable tuber yield of potato was adjusted downwards by $10 \%$ before calculation to represent the actual tuber yield that can be obtained based on the farmers' practices. Sensitivity analysis was also computed using the same data used for the calculation of MRR with the treatments having values greater than $100 \%$. An annual $10 \%$ increase in price of labor cost for the coming 3 years, which make $30 \%$, while keeping the price of produce unchanged was assumed for the conduct of the sensitivity analysis.

2.8. Data Analysis. The analysis of variance was carried out for all of the measured (computed) parameters following the method described by Gomez and Gomez [43]. All yield, yield components, and water use efficiency data were subjected to analysis of variance using the general linear model procedure (Proc GLM) of SAS statistical package version 9.0 [44]. Mean separation was performed using the least significant difference test at the $5 \%$ level of probability.

\section{Results and Discussion}

3.1. Yield and Yield Attributes. The irrigation methods significantly influenced the entire variables measured for potato except for plant height. The level of irrigation water applied during the cropping season also significantly affected the measured parameters except for the number of tubers per plant and plant height (Table 2). The interaction effect of irrigation methods by level of irrigation water, however, was not significant for the variables measured except for the weight of tuber per plant and plant height (Table 2). The results further showed that season was the large source of variation for the variables measured.

The tuber and total biomass yields of potato as well as the weight of tubers per plant were significantly $(p<0.05)$ influenced by irrigation methods (Table 2 ). Irrigating alternate furrows (AFIs) gave the highest tuber yield $\left(35.68 \mathrm{tha}^{-1}\right)$, which was statistically equivalent to the tuber yield ( $\left.34.84 \mathrm{tha}^{-1}\right)$ harvested from the conventional irrigation (CFI) (Table 3). In line with this result, Sarker et al. [9] reported a 5\% increase in the marketable yield of tomato with alternate wetting and drying furrow irrigation method compared to the traditional method. Similarly, conventional and alternate furrow irrigation 
methods provided the highest total biomass yield (45.34 and $44.37 \mathrm{tha}^{-1}$, respectively), which were found statistically equivalent (Table 3 ) but superior compared to irrigating the fixed furrows (FFI). Irrigating fixed furrows throughout the period of cropping season stressed the crop and resulted in statistically lower tuber $\left(28.55 \mathrm{tha}^{-1}\right)$ and total biomass (36.52 $\mathrm{tha}^{-1}$ ) yields than AFI and CFI (Table 3). Compared to irrigating fixed furrows, irrigating alternate furrows and conventional irrigation gave 7.13 tha $^{-1}(25 \%)$ and $6.29 \mathrm{tha}^{-1}(22 \%)$ more tuber yield. The corresponding total biomass yield increments were 7.85 $\mathrm{tha}^{-1}(21 \%)$ and $8.82 \mathrm{tha}^{-1}(24 \%)$, respectively.

Irrigating alternate furrows through partial root drying technique was likely to reduce tuber yield of potato compared to irrigating every furrow [45]. However, in line with the current results, Sarker et al. [14, 46] and Siyal et al. [7] also reported statistically equivalent tuber yield of potato, grain yield of maize, and fruit yield of Okra, respectively, between AFI and CFI treatments. In areas with limited water resources, partial root zone drying (AFI) brought equivalent maize [17], tomato [9], and okra [47] yields and better fruit quality [9]. Bakker et al. [48] also stated no decrease in yield when irrigation water was more frequently applied in alternate furrows in response to crop evapotranspiration demand.

The nonsignificant tuber and biomass yields difference between AFI and CFI could ascribe to the physiological changes that take place during water stress condition. The plant root system was partially wetted under the AFI and FFI methods, which could reduce plant transpiration because of reduced stomatal conductance [7]. Under alternative wetting and drying cycles, the two halves of the plant root system resulted in reduced stomatal opening without significant increase in the leaf water scarcity [49]. For example, Mehrabi and Sepaskhah [50] demonstrated reduced stomatal conductance of $12 \%$ and $7 \%$ in AFI compared to that obtained in CFI in their first and second year, respectively, studies. The root system on the irrigated side of furrows continues absorbing water to meet the water demand of the plant [51]. The partial closure in stomatal conductance did not significantly affect the photosynthesis and dry matter accumulation in plants $[17,50]$. The comparable yield between AFI and CFI could also attribute to the retention of the applied nutrients. This was because nutrient losses could be reduced by limiting the water application as in the case of AFI during the potato growth period [14]. Studies indicated that the partial root zone drying technique increased the total $\mathrm{N}$ and $\mathrm{P}$ use efficiency compared to the traditional full irrigation [52]. However, the extended soil drying as in the case of FFI could reduce the succulent roots for water conduction to main roots [53]. The equivalent tuber and biomass yields from the alternately irrigated furrows compared to the conventional method could also attribute to the higher rate of retention of the supplied irrigation water on clay loam textured soil with relatively lower infiltration capacity $\left(19.2 \mathrm{~cm} \mathrm{day}^{-1}\right)$.

The maximum number of tubers per potato plant (11) was attained from the CFI, which was superior compared to the other two irrigation methods. Irrigating either fixed or alternate furrows brought statistically similar number of tubers per plant (Table 3 ).

The effect of the level of irrigation water applied was not significant on the tuber $(p=0.059)$ and total biomass $(p=0.058)$ yields of potato (Table 2). However, results showed that both tuber and total biomass yields of potato tended to increase with the corresponding increase in the water level. The highest tuber $\left(35.18 \mathrm{tha}^{-1}\right)$ and total biomass $\left(44.93 \mathrm{tha}^{-1}\right)$ yields of potato were harvested from the application of $100 \%$ of the potato water requirement (Table 3). Half-reduced water requirement $\left(50 \% \mathrm{ET}_{\mathrm{C}}\right)$ produced the lowest tuber $\left(28.85 \mathrm{tha}^{-1}\right)$ and total biomass $\left(37.64 \mathrm{tha}^{-1}\right.$ ) yields of potato (Table 3 ). The tuber and total biomass yields of potato declined by $6.3 \mathrm{tha}^{-1}(22 \%)$ and $7.3 \mathrm{tha}^{-1}(20 \%)$, respectively, when irrigated at $50 \%$ of the crop water requirement compared to the $100 \% \mathrm{ET}_{\mathrm{C}}$. The corresponding reduction in tuber and total biomass yields of potato relative $75 \% \mathrm{ET}_{\mathrm{C}}$ were $6.2 \mathrm{tha}^{-1}(21 \%)$ and 6 tha $^{-1}(16 \%)$, respectively, when irrigated at half-reduced water requirement. The current result is in agreement with Badr et al. [54] and Sarker et al. [14], who stated significant reductions on the tuber yield and yield contributing characteristics of potato when less amount of irrigation water was applied. However, the differences between 100 and $75 \% \mathrm{ET}_{\mathrm{C}}$ in terms of tuber and total biomass yields of potato were found negligible (Table 3 ). The equivalent yields of potato [24, 27], teff (Eragrostis tef) [55, 56], onion [26], and maize [21] with 70 or $75 \%$ of the crops water requirement as compared to the optimal irrigation water were also reported in the literature.

When potato, which is among the sensitive crops to drought, is exposed to water stress, it undergoes physiological changes, partially closes its stomata, and suppresses transpiration [51]. In water stress condition, the plant roots secrete hormones and send signals to the shoots, which limit the transpiration by partially closing stomata without hindering photosynthesis and plant growth and yielding enhanced water use efficiency [14, 57]. Studies further indicated that the nutrient uptake may not be necessarily affected [14]. Sarker et al. [46], for example, reported that the uptakes of macro- and micronutrients by maize grain were maintained similar between AFI and CFI under optimal irrigation. The water stress induced by AFI and reduced level of irrigation water enhances the nutrient use by stimulating plant growth through extending the root system to the deeper soil layers $[45,58]$. Thus, controlled irrigation water supply as in the case of $75 \%$ of the crop demand improved the yield by enhancing the plant nutrient-use efficiency [14].

The interaction effect of irrigation methods by level of irrigation water was significant $(p<0.05)$ for the weight of tubers per plant and plant height (Table 2 and Figure 1). The weight of tubers per plant was the highest in the alternate furrows irrigated plots with half-reduced water demand of potato $(1383 \mathrm{~g})$. The same irrigation method along with $75 \%$ of the water demand of potato also brought statistically equivalent weight of tubers per plant (1139g) (Figure 1(a)), which contributed for the attainment of the economically optimum tuber and biomass yields of potato (Section 3.4). The application of 75 and $100 \%$ of the water 


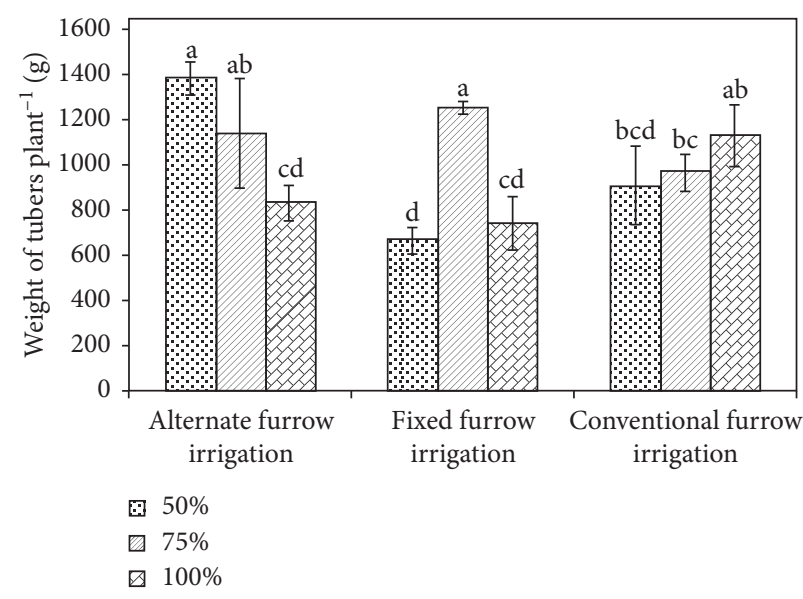

(a)

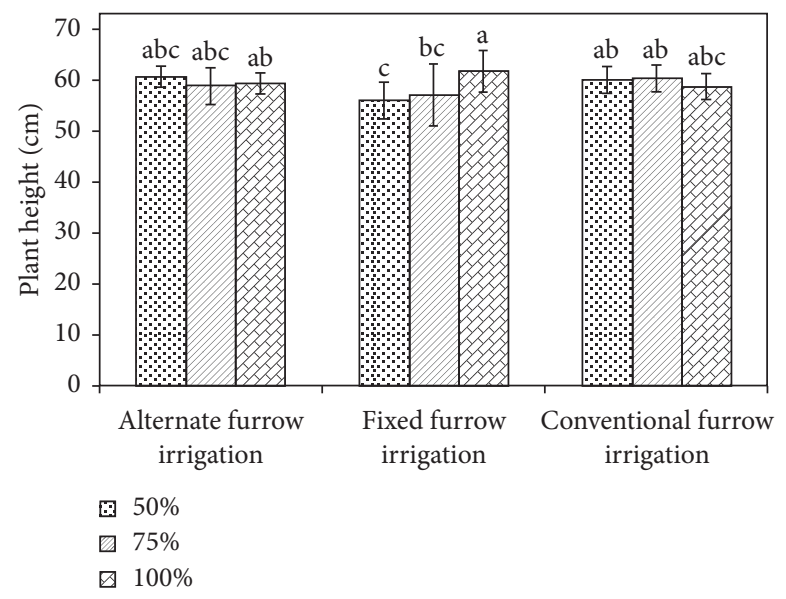

(b)

FIGURE 1: Weight of potato tubers (a) and plant height of potato (b) as affected by the interaction effect of irrigation method by water level.

TABLE 4: The amount of irrigation water saved, tuber yield reduction, and relative water use efficiency with different irrigation methods and amounts.

\begin{tabular}{|c|c|c|c|c|c|c|c|}
\hline $\begin{array}{l}\text { Treatments } \\
\text { Irrigation } \\
\text { method }\end{array}$ & Irrigation level (\%) & $\begin{array}{l}\text { Irrigation amount } \\
\left(\mathrm{mm} \mathrm{ha}^{-1}\right)\end{array}$ & $\begin{array}{l}\text { Tuber yield } \\
\qquad\left(\mathrm{t} \mathrm{ha}^{-1}\right)\end{array}$ & $\begin{array}{c}\text { WUE } \\
\left(\mathrm{kg} \mathrm{m}^{-3}\right)\end{array}$ & $\begin{array}{c}\text { Water saved } \\
(\%)\end{array}$ & $\begin{array}{l}\text { Yield reduction } \\
(\%)\end{array}$ & Relative WUE \\
\hline \multirow{4}{*}{ AFI } & 50 & 113.03 & 31.65 & 28.06 & 74 & 18 & 3.2 \\
\hline & 75 & 169.54 & 37.96 & 22.49 & 62 & 1 & 2.6 \\
\hline & 100 & 226.06 & 37.42 & 16.58 & 49 & 3 & 1.9 \\
\hline & Mean & 169.54 & 35.67 & 22.38 & 62 & 7 & 2.6 \\
\hline \multirow{4}{*}{ FFI } & 50 & 110.08 & 26.54 & 24.31 & 75 & 31 & 2.8 \\
\hline & 75 & 165.12 & 29.39 & 17.99 & 63 & 23 & 2.1 \\
\hline & 100 & 220.17 & 29.72 & 13.59 & 50 & 23 & 1.6 \\
\hline & Mean & 165.12 & 28.55 & 18.60 & 63 & 26 & 2.1 \\
\hline \multirow{4}{*}{ CFI } & 50 & 220.85 & 28.35 & 12.9 & 50 & 26 & 1.5 \\
\hline & 75 & 331.28 & 37.75 & 11.41 & 25 & 2 & 1.3 \\
\hline & 100 & 441.71 & 38.41 & 8.73 & 0 & 0 & 1.0 \\
\hline & Mean & 331.28 & 34.84 & 11.04 & 25 & 9 & 1.3 \\
\hline
\end{tabular}

demand of potato in fixed furrows $(1252 \mathrm{~g})$ and conventional method of irrigation $(1131 \mathrm{~g})$, respectively, also brought statistically equivalent weight of potato tubers per plant. The lowest weight of tubers per plant $(666 \mathrm{~g})$ was harvested from plots irrigated with half-reduced water demand of potato in fixed furrows (Figure 1(a)). Experimental plots irrigated with all levels of irrigation water (50-100\% $\left.\mathrm{ET}_{\mathrm{C}}\right)$ in AFI and CFI methods and irrigated with $100 \%$ in FFI method produced potato that had equivalent heights $(58.8-61.7 \mathrm{~cm}$ ) (Figure 1(b)). The smallest plant height was recorded in plots irrigated with half-reduced water demand of potato in fixed furrow $(56 \mathrm{~cm})$ followed by $75 \%$ water demand of potato in the same method of irrigation $(57.2 \mathrm{~cm})$ (Figure $1(\mathrm{~b}))$.

The measured yield and yield attributes of potato were highly significant $(p<0.01)$ and superior in 2014 than 2013 (Table 2). The number of tubers per plant, weight of tubers per plant, tubers, and total biomass yields of potato were higher by $66,68,37$, and $64 \%$, respectively, in 2014 compared to the 2013 cropping season (Table 3 ).
3.2. Applied Irrigation Water. Owing to variations in the applied irrigation water, the seasonal crop water use differed among treatment means. The total depth of irrigation water supplied to each plot treated with CFI, AFI, and FFI was $331.3,169.5$, and $165.1 \mathrm{~mm}$, respectively. This indicated that the plots treated with AFI consumed approximately half the volume of irrigation water, which saved irrigation water by $49 \%$ without significant yield loss compared to the plots under CFI. Although the highest volume of reduction in irrigation water (50\%) was achieved with FFI, the tuber yield reduction was significant $(23 \%)$ (Table 4$)$. The reduction in the volume of irrigation water under AFI and FFI ascribed to irrigating only alternate (fixed) furrows, which decreased the amount of water by half. It also decreased evapotranspiration and deep percolation losses. The current results align with the $28-35 \%$, $37-39 \%$, 50\%, and 37\% irrigation water savings obtained in potato $[14,22]$, tomato [9], Okra [7], and maize [46], respectively, production with AFI compared to CFI. Kang et al. [59] and Slatni et al. [22] also reported 46-50\% saves in irrigation water due to adoption of AFI as compared to the CFI. 
TABLE 5: Economic analysis based on mean values for potato production for the use of different irrigation methods and levels of irrigation water on potato production.

\begin{tabular}{|c|c|c|c|c|c|c|}
\hline $\begin{array}{l}\text { Treatments } \\
\text { Irrigation } \\
\text { method }\end{array}$ & $\begin{array}{c}\text { Irrigation level } \\
(\%)\end{array}$ & $\begin{array}{l}\text { Adjusted tuber yield } \\
\qquad\left(\mathrm{kg} \mathrm{ha}^{-1}\right)\end{array}$ & $\begin{array}{l}\text { Gross field benefits } \\
\quad\left(\text { US } \$ \mathrm{ha}^{-1}\right)\end{array}$ & $\begin{array}{l}\text { Variable cost } \\
\left(\mathrm{US} \$ \mathrm{ha}^{-1}\right)\end{array}$ & $\begin{array}{l}\text { Net benefit (US\$ } \\
\mathrm{ha}^{-1} \text { ) }\end{array}$ & $\begin{array}{l}\text { Marginal rate of } \\
\text { return }\end{array}$ \\
\hline AFI & 50 & 28485 & 12947.73 & 68.18 & 12879.55 & - \\
\hline FFI & 50 & 23886 & 10857.27 & 68.18 & 10789.09 & $\mathrm{D}$ \\
\hline AFI & 75 & 34164 & 15529.09 & 102.27 & 15426.82 & 74.72 \\
\hline FFI & 75 & 26451 & 12023.18 & 102.27 & 11920.91 & $\mathrm{D}$ \\
\hline AFI & 100 & 33678 & 15308.18 & 136.36 & 15171.82 & $\mathrm{D}$ \\
\hline FFI & 100 & 26748 & 12158.18 & 136.36 & 12021.82 & $\mathrm{D}$ \\
\hline CFI & 50 & 25515 & 11597.73 & 136.36 & 11461.36 & $\mathrm{D}$ \\
\hline CFI & 75 & 33975 & 15443.18 & 204.55 & 15238.64 & $\mathrm{D}$ \\
\hline CFI & 100 & 34569 & 15713.18 & 272.73 & 15440.45 & 0.2 \\
\hline
\end{tabular}

Note: D means dominated due the greater variable cost but lower net benefit.

3.3. Water Use Efficiency. The irrigation methods brought highly significant $(p<0.001)$ differences in WUE of potato (Table 2). The highest and statistically superior WUE of potato $\left(22.4 \mathrm{~kg} \mathrm{~m}^{-3}\right)$ was achieved from the alternate furrow irrigated plots followed by fixed furrows irrigated plots $\left(18.6 \mathrm{~kg} \mathrm{~m}^{-3}\right)$ during this study (Table 4$)$. This implies that the WUE was significantly $(p<0.001)$ increased in AFI by around $50 \%$ compared to CFI. The CFI method $\left(11.0 \mathrm{~kg} \mathrm{~m}^{-3}\right)$ resulted in lower WUE of potato indicating the consumption of huge amount irrigation water without significant increase in tuber yield. This further implies the loss of substantial volume of irrigation water due to evapotranspiration and deep percolation. Irrigating alternate furrows provided $11.3 \mathrm{~kg}(103 \%)$ extra tuber yield against the conventional irrigation per unit volume of water (Table 4). This implies the great potential of doubling the cultivable land and production using the existing irrigation water resource by shifting from the conventional to water-saving irrigation technique. The adoption of the water-saving irrigation method further helps to minimize the adverse effects of excess irrigation to the environments and the conflicts among the community for the limited water resource.

The increased WUE of potato with AFI ascribed to the reduced amount of irrigation water without significant reduction in potato tuber yield. The current result is in agreement with Khalili et al. [21], who reported $27 \%$ and $17 \%$ increases in stover and grain, respectively, yields of maize with AFI compared to CFI. It is also in agreement with Sarker et al. [14], who reported 35\% increase in water productivity of potato with AFI compared to CFI while preserving grain yield. Siyal et al. [7] also reported the highest water productivity of $5.29 \mathrm{~kg} \mathrm{~m}^{-3}$ with AFI as contrasted to the $2.78 \mathrm{~kg} \mathrm{~m}^{-3}$ with CFI in okra production. The highest crop water productivity with AFI method was also reported for maize [60], tomato [9], and other crops.

The amount of irrigation water applied during the cropping season highly significantly $(p<0.001)$ influenced the WUE of potato (Table 2). Decreasing the water demand of potato by half provided the highest WUE of potato $\left(21.8 \mathrm{~kg} \mathrm{ha}^{-1}\right)$ followed by $75 \%\left(17.3 \mathrm{~kg} \mathrm{ha}^{-1}\right)$ demand of the potato water requirement, which were statistically different to each other (Table 3). The lowest WUE $\left(13.0 \mathrm{~kg} \mathrm{ha}^{-1}\right)$ was recorded from the application of $100 \%$ of the water demand. Decreasing the water demand of potato by 50 and $25 \%$ in the study area increased the WUE by $8.8 \mathrm{~kg}(68 \%)$ and $4.3 \mathrm{~kg}(33 \%)$, respectively, relative to the application of full demand per unit volume of irrigation water. Despite the highest WUE with half-reduced demand of irrigation water, the penalty in tuber yield of potato was significant (25\%) (Table 4). The current result is in agreement with Kifle and Gebretsadikan [24] and Gebremariam et al. [27], who reported equivalent tuber yield of potato with $25 \%$ and $30 \%$, respectively, deficit throughout the growing season as compared to the optimal irrigation. Improved water productivity with up to $20 \%$ irrigation water deficit was also reported by El-Hendawy et al. [61] and El-Mageed and Semida [62].

The WUE of potato was significantly $(p<0.01)$ higher by $46 \%$ in 2014 compared to 2013 cropping season (Table 3). The lower tuber yield in 2013 cropping season attributed to the reduced WUE.

3.4. Economic Analysis. The methods and levels of irrigation water had great influence on profitability of potato production (Table 5). Irrigating alternate furrows using $25 \%$ less water was superior to the other irrigation methods and levels of irrigation and economically profitable since it gave acceptable rate of return in excess of $100 \%$ (Table 5). Application of $75 \%$ of the potato water requirement in alternate furrows could enable farmers to save significant amount irrigation water and to earn a very high return of US\$74.72 for every US $\$ 1.0$ investment on labor for irrigating the potato plants, which result in an attractive increase in farmers' income (Table 5). The saved $25 \%$ of irrigation water could enable farmers to cultivate additional agricultural fields with the available resource and to generate extra income, which was not included in the computation of economic profitability. The economic profitability agrees with the agronomic results.

In line with this study, Sarker et al. [9] reported higher benefit to cost ratio of 11.0 and $10.4 \%$ with alternate wetting and drying furrow irrigation method and fixed wetting and drying furrow irrigation method, respectively, than 
conventional furrow irrigation; when tomato was irrigated with $80 \%$ of the field capacity. Shang and Tisdell [63] reported that irrigation techniques, operating costs, and level of production influenced the net return in irrigation. The other treatments, either dominated or the MRR less than $100 \%$, brought lower revenue to farmers compared to irrigating alternate furrows with $25 \%$ deficit.

The sensitivity analysis with the possible higher price for the labor cost confirmed that the MRR was above $100 \%$ suggesting that the same recommendation could still work well. If the price of labor cost increase by $30 \%$ within the coming 3 years, farmers who can alternately irrigate furrows using $75 \%$ of the potato water requirement earn additional US\$57.25 for every US\$1.0 investment on labor for irrigation.

\section{Conclusion and Recommendation}

Results of our field study demonstrated that potato yield, yield attributes, and water use efficiency (WUE) were significantly influenced by irrigation method and level. Irrigating alternate furrows (AFI) consumed approximately half the volume of irrigation water relative to conventional furrow irrigation (CFI). AFI provided the highest tuber yield regardless of the reduction in the total volume of irrigation water, which was found statistically equivalent to the tuber yield harvested from irrigating every furrow techniques. Thus, irrigating alternate furrows resulted in $49 \%$ higher WUE without significant yield decline. Reducing the potato water demand by $25 \%$ enhanced the WUE by $33 \%$ with equivalent tuber yield to the application of $100 \%$ of the potato water requirement. Furthermore, irrigating alternate furrows with $25 \%$ reduced potato water requirement gave the highest net return of US $\$ 74.72$ for every US\$1.0 investment on labor for irrigating the potato plant. The authors of this study, therefore, concluded that irrigating alternate furrows in conjunction with $25 \%$ less the potato water demand saved irrigation water, increased water use efficiency without compromising tuber yield, and enhanced economic return for farmers in semiarid areas. Adoption of this technique suggests the great potential of doubling the cultivable land and production using the existing irrigation water resource by shifting from the conventional to watersaving irrigation method. Adoption of the water-saving irrigation methods further helps to minimize the adverse effects of excess irrigation to the environments and the conflicts among the community for the limited water resource.

\section{Data Availability}

The data used to support the findings of this study are available from the corresponding author upon request.

\section{Conflicts of Interest}

The authors declare that they have no conflicts of interest regarding the publication of this paper.

\section{Acknowledgments}

The authors would like to thank the Kulumsa Agricultural Research Center for the provision of logistics for the execution of this research activity. The authors would like to acknowledge all members of the Land and Water Resources research division for their efforts in land, crop, and data management during the conduct of this study. This research was financially supported by the Ethiopian Institute of Agricultural Research.

\section{References}

[1] T. Hordofa, M. Michael, B. Sileshi, and E. Teklu, "Irrigation and rain-fed crop production system in Ethiopia," in Impact of Irrigation on Poverty and Environment in Ethiopia, pp. 27-36, International Water Management Institute, Addis Ababa, Ethiopia, 2008.

[2] B. Yalew, K. Hussein, B. Ermias, and N. Sorssa, Small-scale irrigation situation analysis and capacity needs assessment, a tripartite cooperation between Germany, Israel and Ethiopia, Natural Resources Management Directorate through the Support of GIZ. Sustainable Land Management Program, Ministry of Agriculture, Addis Ababa, Ethiopia, 2011.

[3] W. Teshome, Irrigation practices, state intervention and farmer's life-worlds in drought-pone Tigray, Ethiopia, Ph.D. thesis, Wageningen University, Wageningen, Netherlands, 2003.

[4] E. Yazew, Development and Management of Irrigated Lands in Tigray, Ethiopia, PhD Dissertation, Balkema Publishers, Taylor \& Francis Group plc, London, UK, 2005.

[5] T. Ayenew, "Water management problems in the Ethiopian rift: challenges for development," Journal of African Earth Sciences, vol. 48, no. 2-3, pp. 222-236, 2007.

[6] P. Debaeke and A. Aboudrare, "Adaptation of crop management to water-limited environments," European Journal of Agronomy, vol. 21, no. 4, pp. 433-446, 2004.

[7] A. A. Siyal, A. S. Mashori, K. L. Bristow, and M. T. Van Genuchten, "Alternate furrow irrigation can radically improve water productivity of okra," Agricultural Water Management, vol. 173, pp. 55-60, 2016.

[8] R. K. Koech, R. J. Smith, and M. H. Gillies, "A real-time optimisation system for automation of furrow irrigation," Irrigation Science, vol. 32, no. 4, pp. 319-327, 2014.

[9] K. K. Sarker, M. A. R. Akanda, S. K. Biswas, D. K. Roy, A. Khatun, and M. A. Goffar, "Field performance of alternate wetting and drying furrow irrigation on tomato crop growth, yield, water use efficiency, quality and profitability," Journal of Integrative Agriculture, vol. 15, no. 10, pp. 2380-2392, 2016.

[10] FAO, Guidelines for Predicting Crop Water requirement: Irrigation and Drainage Paper No. 24, Food and Agriculture Organization of the United Nations, Rome, Italy, 1997.

[11] A. S. Ati, A. D. Iyada, and S. M. Najim, "Water use efficiency of potato (Solanum tuberosum L.) under different irrigation methods and potassium fertilizer rates," Annals of Agricultural Sciences, vol. 57, no. 2, pp. 99-103, 2012.

[12] A. Hezarjaribi, A. A. Dehghani, M. M. Helghi, and A. Kiani, "Hydraulic performances of various trickle irrigation emitters," Journal of Agronomy, vol. 7, no. 3, pp. 265-271, 2008.

[13] Z. Lincoln, M. S. Johannes, D. D. Michael, M. C. Rafael, and I. Jason, "Tomato yield, biomass accumulation, root distribution and irrigation water use efficiency on a sandy soil, as 
affected by nitrogen rate and irrigation scheduling," Agricultural Water Management, vol. 96, no. 1, pp. 23-34, 2009.

[14] K. K. Sarker, A. Hossain, J. Timsina et al., "Yield and quality of potato tuber and its water productivity are influenced by alternate furrow irrigation in a raised bed system," Agricultural Water Management, vol. 224, Article ID 105750, 2019.

[15] T. Du, S. Kang, J. Sun, X. Zhang, and J. Zhang, "An improved water use efficiency of cereals under temporal and spatial deficit irrigation in north China," Agricultural Water Management, vol. 97, no. 1, pp. 66-74, 2010.

[16] M. G. Horst, S. S. Shamutalov, L. S. Pereira, and J. M. Gonçalves, "Field assessment of the water saving potential with furrow irrigation in fergana, aral sea basin," Agricultural Water Management, vol. 77, no. 1-3, pp. 210-231, 2005.

[17] S. Kang, Z. Liang, Y. Pan, P. Shi, and J. Zhang, "Alternate furrow irrigation for maize production in an arid area," Agricultural Water Management, vol. 45, no. 3, pp. 267-274, 2000.

[18] C. R. Jensen, A. Battilani, F. Plauborg et al., "Deficit irrigation based on drought tolerance and root signalling in potatoes and tomatoes," Agricultural Water Management, vol. 98, no. 3, pp. 403-413, 2010.

[19] Z. Jovanovic, R. Stikic, B. Vucelic-Radovic et al., "Partial rootzone drying increases WUE, $\mathrm{N}$ and antioxidant content in field potatoes," European Journal of Agronomy, vol. 33, no. 2, pp. 124-131, 2010.

[20] A. R. Sepaskhah and S. H. Ahmadi, "A review on partial rootzone drying irrigation," International Journal of Plant Production, vol. 4, no. 4, pp. 1735-6814, 2010.

[21] F. Khalili, F. Aghayari, and M. R. Ardakani, "Effect of alternate furrow irrigation on maize productivity in interaction with different irrigation regimes and biochar amendment," Communications in Soil Science and Plant Analysis, vol. 51, no. 6, pp. 757-768, 2020.

[22] A. Slatni, K. Zayani, A. Zairi, S. Yacoubi, R. Salvador, and E. Playán, "Assessing alternate furrow strategies for potato at the Cherfech irrigation district of Tunisia," Biosystems Engineering, vol. 108, no. 2, pp. 154-163, 2011.

[23] K. Xie, X.-X. Wang, R. Zhang et al., "Partial root-zone drying irrigation and water utilization efficiency by the potato crop in semi-arid regions in China," Scientia Horticulturae, vol. 134, pp. 20-25, 2012.

[24] M. Kifle and T. G. Gebretsadikan, "Yield and water use efficiency of furrow irrigated potato under regulated deficit irrigation, Atsibi-Wemberta, North Ethiopia," Agricultural Water Management, vol. 170, pp. 133-139, 2016.

[25] K. Abdullah, G. Tuylua, U. Yusuf, and B. Cakmak, "Crop water use of onion (Allium cepa L.) in Turkey," Agricultural Water Management, vol. 72, pp. 59-62, 2005.

[26] S. Bekele and K. Tilahun, "Regulated deficit irrigation scheduling of onion in a semiarid region of Ethiopia," $A g$ ricultural Water Management, vol. 89, no. 1-2, pp. 148-152, 2007.

[27] H. L. Gebremariam, K. Welde, and K. D. Kahsay, "Optimizing yield and water use efficiency of furrow-irrigated potato under different depth of irrigation water levels," Sustainable Water Resources Management, vol. 4, no. 4, pp. 1043-1049, 2018.

[28] CSA (Central Statistical Agency), Report on area and production of major crops for 2017/2018 (private peasant holdings, Meher Season, 2018.

[29] W. Gebremedhin, G. Endale, and B. Lemaga, "Potato agronomy," in Root and Tuber Crops: The Untapped Resources, W. Gebremedhin, G. Endale, and B. Lemaga, Eds., pp. 33-36,
Ethiopian Institute of Agricultural Research, Addis Ababa, Ethiopia, 2008.

[30] CSA (Central Statistical Agency), Report on area and production of major crops for 2017/2018 (private peasant holdings, Meher Season, 2008.

[31] FAOSTAT, Statistical Databases, Crops Data, Food and Agriculture Organization of the United Nations, Rome, Italy, 2018.

[32] IUSS Working Group WRB, "International soil classification system for naming soils and creating legends for soil maps," World Reference Base for Soil Resources 2014, World Soil Resources Reports No. 106, Food and Agricultural Organization of the United Nations, Rome, Italy, 2014.

[33] T. Tekalign, Soil, Plant, Water, Fertilizer, Animal Manure and Compost analysis, International Livestock Research Center for Africa, Addis Ababa, Ethiopia, Working Document No. 13, 1991.

[34] J. R. Landon, Booker Tropical Soil Manual Hand Book for Soil Survey and Agricultural Land Evaluation in the Tropical and Sub Tropics, p. 474p, Taylor \& Francis, Oxfordshire, UK, 1991.

[35] FAO, "New_LocClim: local climate estimator," Environment and Natural Resources Working Paper No. 20, Food and Agriculture Organization of United Nations, Rome, Italy, 2005.

[36] FAO, World-wide agroclimatic dataset. Environment and Natural Resources, Working paper No. 5, FAO, Rome, Italy, 2001.

[37] R. G. Allen, L. S. Pereira, D. Raes, and M. Smith, Crop Evapotranspiration Guidelines for Computing Crop Water requirements: Irrigation and Drainage Paper No. 56, Food and Agriculture Organization of the United Nations (FAO), Rome, Italy, 1998.

[38] S. Martin, CROPWAT: A Computer Program for Irrigation Planning and Management: Irrigation and Drainage Paper No. 46, Food and Agriculture Organization of the United Nations, Rome, Italy, 1996.

[39] C. Brouwn, K. Prins, and M. Heibloem, Irrigation Water Management: Irrigation Scheduling Training Manual, No 4, Food and Agriculture Organization of the United Nations, Rome, Italy, 1989.

[40] M. G. Bos, "Summary of ICID definitions of irrigation efficiency," ICID Bulletin, vol. 34, pp. 28-31, 1985.

[41] T. Chapagain and E. Yamaji, "The effects of irrigation method, age of seedling and spacing on crop performance, productivity and water-wise rice production in Japan," Paddy and Water Environment, vol. 8, no. 1, pp. 81-90, 2010.

[42] CIMMYT (International Maize and Wheat Improvement Centre), From Agronomic Data to Farmer Recommendation: An Economics Training Manual (No 27), CIMMYT, Mexico City, Mexico, 1988.

[43] K. A. Gomez and A. A. Gomez, Statistical Procedure for Agricultural Research, Wiley, Hoboken, USA, 2nd edition, 1984.

[44] SAS Institute, SAS Institute SAS/STAT User's Guide, SAS Institute Inc, Cary, NC, USA, 2002.

[45] F. Liu, A. Shahnazari, M. N. Andersen, S.-E. Jacobsen, and C. R. Jensen, "Effects of deficit irrigation (DI) and partial root drying (PRD) on gas exchange, biomass partitioning, and water use efficiency in potato," Scientia Horticulturae, vol. 109, no. 2, pp. 113-117, 2006.

[46] K. K. Sarker, A. Hossain, J. Timsina et al., "Alternate furrow irrigation can maintain grain yield and nutrient content, and increase crop water productivity in dry season maize in sub-tropical climate of South Asia," Agricultural Water Management, vol. 238, Article ID 106229, 2020. 
[47] P. Panigrahi, N. N. Sahu, and S. Pradhan, "Evaluating partial root-zone irrigation and mulching in okra (Abelmoschus esculentus L.) under a sub-humid tropical climate," Journal of Agriculture and Rural Development in the Tropics and Subtropics, vol. 112, no. 2, pp. 169-175, 2011.

[48] D. M. Barker, S. R. Raine, and M. J. Robertson, "A preliminary investigation of alternate furrow irrigation for sugar cane production," in Proceedings of 19th Conference of the Australian Society of Sugar Cane Technologists, vol. 20, pp. 302309, Cairns, Australia, April 1997.

[49] J. Zhang, U. Schurr, and W. J. Davies, "Control of stomatal behaviour by abscisic acid which apparently originates in the roots," Journal of Experimental Botany, vol. 38, no. 7, pp. 1174-1181, 1987.

[50] F. Mehrabi and A. R. Sepaskhah, "Partial root zone drying irrigation, planting methods and nitrogen fertilization influence on physiologic and agronomic parameters of winter wheat," Agricultural Water Management, vol. 223, Article ID 105688, 2019.

[51] S. H. Ahmadi, M. N. Andersen, F. Plauborg et al., "Effects of irrigation strategies and soils on field grown potatoes: gas exchange and xylem," Agricultural Water Management, vol. 97, pp. 1486-1494, 2010.

[52] Y. L. Han and S. Z. Kang, "Effects of controlled partial rootzone irrigation on root nutrition uptake of maize (Zea mays L.)," Transactions of the Chinese Society of Agricultural Engineering, vol. 18, pp. 57-59, 2002.

[53] F. Li, J. Liang, S. Kang, and J. Zhang, "Benefits of alternate partial root-zone irrigation on growth, water and nitrogen use efficiencies modified by fertilization and soil water status in maize," Plant and Soil, vol. 295, no. 1-2, pp. 279-291, 2007.

[54] M. A. Badr, W. A. El-Tohamy, and A. M. Zaghloul, "Yield and water use efficiency of potato grown under different irrigation and nitrogen levels in an arid region," Agricultural Water Management, vol. 110, pp. 9-15, 2012.

[55] A. Tsegay, E. Vanuytrecht, B. Abrha, J. Deckers, K. Gebrehiwot, and D. Raes, "Sowing and irrigation strategies for improving rainfed tef (eragrostis tef (Zucc.) trotter) production in the water scarce Tigray region, Ethiopia," Agricultural Water Management, vol. 150, pp. 81-91, 2015.

[56] Y. M. Yihun, A. M. Haile, B. Schultz, and T. Erkossa, "Crop water productivity of irrigated teff in a water stressed region," Water Resources Management, vol. 27, no. 8, pp. 3115-3125, 2013.

[57] W. J. Davies and J. Zhang, "Root signals and the regulation of growth and development of plants in drying soil," Annual Review of Plant Physiology and Plant Molecular Biology, vol. 42, no. 1, pp. 55-76, 1991.

[58] T. Hu, S. Kang, F. Li, and J. Zhang, "Effects of partial rootzone irrigation on the nitrogen absorption and utilization of maize," Agricultural Water Management, vol. 96, no. 2, pp. 208-214, 2009.

[59] S. Z. Kang, P. Shi, Y. H. Pan, Z. S. Liang, X. T. Hu, and J. Zhang, "Soil water distribution, uniformity and water-use efficiency under alternate furrow irrigation in arid areas," Irrigation Science, vol. 19, no. 4, pp. 181-190, 2000 b.

[60] S. Kang and J. Zhang, "Controlled alternate partial root-Zone irrigation: its physiological consequences and impact on water use efficiency," Journal of Experimental Botany, vol. 55, no. 47, pp. 2437-2446, 2004.

[61] S. E. El-Hendawy, M. A. Kotab, N. A. Al-Suhaibani, and U. Schmidhalter, "Optimal coupling combinations between the irrigation rate and glycinebetaine levels for improving yield and water use efficiency of drip-irrigated maize grown under arid conditions," Agricultural Water Management, vol. 140 , pp. $69-78,2014$.

[62] T. A. A. El-Mageed and W. M. Semida, "Effect of deficit irrigation and growing seasons on plant water status, fruit yield and water use efficiency of squash under saline soil," Scientia Horticulturae, vol. 186, pp. 89-100, 2015.

[63] Y. C. Shang and C. A. Tisdell, "Economic decision making in sustainable aquaculture development," in Sustainable Aquaculture, J. E. Bardach, Ed., pp. 127-148, John Wily and Sons, Hoboken, USA, 1997. 